\title{
Outcome from "rescue clipping" of ruptured intracranial aneurysms during induction anaesthesia and endotracheal intubation
}

\author{
SA TSEMENTZIS, ER HITCHCOCK \\ From the Department of Neurosurgery, University of Birmingham, UK
}

SUMMARY Eight patients with ruptured aneurysms during induction anaesthesia and endotracheal intubation underwent an emergency "rescue clipping" of their lesion. Three patients died. Of the five survivors three made a good final recovery, one patient was moderately disabled and one remained in coma. Conservative management of this crisis is doomed to failure but the comparatively good outcome of the operative cases supports emergency "rescue clipping".

There appear to be no published reports on the nature and significance of haemorrhage from a ruptured aneurysm during induction anaesthesia and endotracheal intubation. Once it has been recognised, the patient is either returned to the ward on supportive conservative treatment and, should he survive, another attempt at elective surgery is then undertaken, or the operation is continued. Past experience indicates that under these circumstances patients almost invariably die. The outcome is reported of eight patients who had "rescue clipping" of aneurysms which ruptured during induction anaesthesia and endotracheal intubation.

\section{Material and methods}

\section{(a) Cases}

Eight patients of a total of $404(2 \%)$ operation inductions for aneurysmal surgery rebled during induction and immediately thereafter underwent an emergency "rescue clipping" of their aneurysm. There were six females and two males; with ages between 33 to 60 years. All patients had previously had uneventful retrograde right brachial angiography or direct carotid angiography under endotracheal general anaesthesia.

Address for reprint requests: SA Tsementzis MD, Midland Centre for Neurosurgery \& Neurology, Holly Lane, Smethwick, Warley, West Midlands, B67 7JX, UK.

Received 16 March 1984 and in final revised form 25 July 1984. Accepted 27 July 1984

\section{(b) Anaesthetic details}

The patients studied were evenly distributed amongst fo $\overrightarrow{\mathbb{D}} 0$ anaesthetists with varied anaesthetic techniques. Althesi suxamethonium and thiopentone were used for induction $T$ and maintained with fentanyl, droperidol, allagarim, $\mathbb{D}$ etomidate, $\mathrm{N}_{2} \mathrm{O} / \mathrm{O}_{2}$ mixture in different combinations Comments such as "difficult", "awkward intubation "coughed during intubation" were made on three patients. In two other adult patients a small (No 8 Portex) size $\vec{\varphi}$ endotracheal tube was used after failure to pass a standard or No 9. In two further patients relaxation was achieved only after a second dose of suxamethonium but in the eighth patient there was no indication of difficult intubation. Oropharyngeal local anaesthesia to suppress vagal stimula- $\bar{\partial}$ tion during intubation was not used in any of our patients. Neither alpha nor beta adrenergic blocking agents were $\mathbb{D}$ given prior to or during intubation and induction anaesthesia.

\section{(c) Per-operative details}

Blood pressure was measured directly via a radial catheter using a Hewlett-Packard transducer and monitor throughout the operation. The following observations were generally made in all patients. During the scalp incision the surgeon commented on excessive blood ooze although 3 intra-arterial pressure during this period showed no elevation. After turning the flap, however, the initial suspicion $\frac{0}{3}$ of rebleeding was confirmed. The dura and underlying brain were extremely tight with subdural fresh blood and 을 active arterial bleeding from the aneurysm site. Brain swel- $D$ ling was little relieved by ventricular puncture or infusion 을 of $20 \%$ mannitol. Only when the blood pressure was reduced to levels of $60 \mathrm{~mm} \mathrm{Hg}$ systolic level, was swelling o reduced sufficiently to allow the surgeon to retract the $N$ 
Table

\begin{tabular}{|c|c|c|c|c|c|c|c|}
\hline \multirow{2}{*}{$\underset{(y r)}{\text { Age-Sex }}$} & \multirow[t]{2}{*}{ Site of aneurysm } & \multirow{2}{*}{\multicolumn{2}{|c|}{$\begin{array}{l}\text { Days elapsed } \\
\text { (from haemorrhage } \\
\text { to surgery) }\end{array}$}} & \multicolumn{2}{|c|}{ Management data $\left({ }^{*}\right)$} & \multicolumn{2}{|l|}{ Outcome } \\
\hline & & & & Pre-operative & Post-operative & GOS (†) & $\begin{array}{l}\text { Latest review } \\
\text { from surgery } \\
\text { (months) }\end{array}$ \\
\hline $\begin{array}{l}45, \mathrm{~F} \\
38, \mathrm{M} \\
60, \mathrm{~F} \\
58, \mathrm{~F} \\
42, \mathrm{~F} \\
45, \mathrm{M} \\
33, \mathrm{~F} \\
35, \mathrm{~F}\end{array}$ & $\begin{array}{l}\text { Bifurcation middle cerebral } \\
\text { Bifurcation middle cerebral } \\
\text { Pericallosal } \\
\text { Anterior communicating } \\
\text { Posterior communicating } \\
\text { Posterior communicating } \\
\text { Bifurcation middle cerebral } \\
\text { Anterior communicating }\end{array}$ & $\begin{array}{r}9 \\
8 \\
9 \\
7 \\
32 \\
6 \\
10 \\
7\end{array}$ & & $\begin{array}{l}\text { C } \\
\text { A, D } \\
\text { C, D, E, I } \\
\bar{D}, \text { G } \\
\text { C, D, E } \\
\text { A, C, D } \\
\text { D }\end{array}$ & $\begin{array}{l}\text { B, D, E, G } \\
\text { A, B, E, I, J } \\
\text { B, G, H } \\
\text { B, E, G, H, I } \\
\text { B, G } \\
\text { B, E, G, J } \\
\text { E, J } \\
\text { A, B, E }\end{array}$ & $\begin{array}{l}2 \\
1 \\
5 \\
5 \\
1 \\
5 \\
1 \\
4\end{array}$ & $\begin{array}{l}24 \\
\frac{18}{-} \\
\frac{24}{24} \\
12\end{array}$ \\
\hline \multicolumn{2}{|c|}{$\begin{array}{ll}\text { (*) }^{*} & \text { Management data } \\
\text { A } & \text { Sedatives, tranquillizers } \\
\text { B } & \text { Anticonvulsants } \\
\text { C } & \text { Narcotics, analgesics } \\
\text { D } & \text { Antifibrinolytics } \\
\text { E } & \text { Steroids } \\
\text { G } & \text { Mannitol } \\
\text { H } & \text { Dextran } \\
\text { I } & \text { Ventricular CSF drainage } \\
\text { J } & \text { ICP monitoring }\end{array}$} & \multicolumn{5}{|c|}{$\begin{array}{l}\text { GOS (Glasgow Outcome Scale) } \\
\text { 1. Good recovery: Patient can lead a full and } \\
\text { independent life with or without minimal } \\
\text { neurological deficit. } \\
\text { 2. Moderately disabled: Patient having neurological } \\
\text { or intellectual impairment but is independent. } \\
\text { 3. Severely disabled: Conscious patient but totally } \\
\text { dependent on others to get through the } \\
\text { activities of the day. } \\
\text { 4. Vegetative survival. } \\
\text { 5. Dead. }\end{array}$} & \\
\hline
\end{tabular}

brain and clip the aneurysm neck in the usual manner. In one patient (CT, 35, F; table) hypotension could not be induced and partial frontal lobe resection was necessary to achieve exposure. The outcome at the end of a 2 year follow-up period was assessed on the Glasgow Outcome Scale. ${ }^{1}$

\section{(d) Immediate post-operative management}

All patients were able to breathe spontaneously and deliberate mechanical ventilation was not used. The patients remained in the intensive care unit for a few days until their condition was stable and satisfactory.

\section{Results}

All patients were grade I to II (Botterell classification) immediately before operation. Immediately after operation all eight patients were breathing spontaneously. Three patients were stuporous and one was mute, all with severe focal deficits including cranial nerve involvement; of the remaining four patients who regained consciousness only one (BH, 42, F) was left with focal neurological deficits.

The table lists aneurysm site, time elapsed from ictus to surgery, pre- and post-operative supportive conservative treatment and the final outcome and date of latest review. Three patients died (mortality rate $37.5 \%)$. Of the survivors $(62.5 \%)$ three $(37.5 \%)$ made a good recovery at the end of 12 to 18 months; one $(12.5 \%)$ was moderately disabled and the other remained comatose.

\section{Discussion}

The risk of spontaneous recurrent haemorrhage after subarachnoid haemorrhage varies from 14$30 \%$ being highest between the 7 th to 14 th day from ictus. $^{2-4}$ The peak incidence of recurrent haemorrhage coincides with lysis of blood clot by fibrinolytic activity but there is the additional risk of recurrent haemorrhage particularly during angiography as well as induction anaesthesia and endotracheal intubation.

Angiographic procedures may be responsible for aneurysmal rupture and subsequent leakage of contrast material into the surrounding subarachnoid spaces and tissues. ${ }^{5}$ The prognosis from ruptured aneurysm during angiography is very poor and of the 31 cases reported to date $27(75 \%)$ died. Only two $(6.4 \%)$ of the remaining seven survivors made a complete recovery whereas five developed disability. ${ }^{6}$

Tachycardia and hypertension are well documented complications of laryngoscopy and tracheal intubation in normotensive patients under a variety of anaesthetic techniques ${ }^{7-10}$ similar to the ones used in this study. These hypertensive responses of normal subjects might be enhanced and prove dangerous to hypertensive subjects during intubation, even if the latter are under well controlled antihypertensive therapy. " The precise cause of the cardiovascular changes following intubation is uncertain. It could, however, be adequately explained on the basis of a reflex sympathetic response to the mechanical stimulation of larynx and trachea. Contributory factors of hypertension and tachycardia may well be due to a continued preoperative anxiety or reflex baroreceptor effect due to minor hypotension after thiopentone and possibly due to suxamethonium. ${ }^{12-14}$ These factors appear to 
be less important than local laryngotracheal stimulation, particularly since the maximum rise in blood pressure follows endotracheal stimulation. Moreover, it has been shown in cats that the hypertensive response during intubation is due to increased activity of the cardiac sympathetic nerves and that the pattern of the cardiovascular changes was almost identical to man's. ${ }^{\text {is }}$

Although transient arterial hypertension and tachycardia are probably unimportant in most patients, in certain patients myocardial ischaemia, ${ }^{16}$ left ventricular failure ${ }^{14}$ and cerebral haemorrhage, ${ }^{17}$ may occur. Attempts to control these responses have included the administration of various adrenergic blocking agents systemically as well as oropharyngeal local anaesthesia..$^{18}$ Both alpha ${ }^{19} 20$ and beta blocking agents ${ }^{2021}$ have been successfully used in suppressing the cardiovascular changes during intubation and induction anaesthesia. The effectiveness of adrenergic blocking therapy during induction and intubation of cases with ruptured aneurysm seems worth further study.

The prognosis of recurrent haemorrhage during pre-operative induction is better than that for angiography. The incidence of operative induction haemorrhage is difficult to estimate because the condition has not been reported as such. Girvin ${ }^{22}$ noted incidentally that three of 66 patients $(4.6 \%)$ receiving tranexamic acid had operative induction haemorrhage. Immediate operation and evacuation of clot or decompression may be of crucial importance by relieving the enormous rise of intracranial pressure. Massive increase in intracranial pressure at the time of haemorrhage is well documented. ${ }^{23}$ There was indeed every indication of raised intracranial pressure during the emergency operation with excessive scalp bleeding, dural and brain "tightness", and no response to anti-oedema agents. Hypotension, however, and resultant hypoperfusion produces improvement suggesting that brain swelling rather than oedema is the cause. Mannitol and steroids even in large quantities therefore are ineffective in reducing intracranial hypertension. The immediate reduction of intracranial hypertension prevents or eliminates further mechanical and hypoxic brain damage and prevents the transient physiological lesion from becoming irreversible. Such an injury is manifest by the patient's neurological condition and in particular his level of consciousness. The post-operative state of consciousness is of great prognostic importance. Patients who recovered consciousness immediately after the procedure had a very good to excellent recovery. In contrast those who failed to regain consciousness either died or remained in a vegetative state. Conservative management of this crisis is doomed to failure but the excellent outcome in the operated cases recommended emergency "rescue clipping" of $\mathbb{\Phi}$ ruptured aneurysms during induction anaesthesia and endotracheal intubation. We would emphasise, $\stackrel{\circ}{\subset}$ however, that this is only possible by prompt andô skilful anaesthetic management.

We are grateful to our anaesthetic colleagues for their helpful, honest comments upon the anaesthetic $\vec{F}$ records and thank Veronica Turner for typing the manuscript.

\section{References}

1 Jennett B, Bond M. Assessment of outcome after severe brain damage. A practical scale. Lancet 1975;i:480-4.

${ }^{2}$ Mullan S. The initial medical management of ruptured intracranial aneurysms. In: Morley TP, ed. Current Controversies in Neurosurgery. London: WB Saunders Co, 1976:259-69.

${ }^{3}$ Winn HR, Richardson AE, James JA. Late morbidity and mortality in cerebral aneurysms: a ten year $\infty$ follow-up of 364 conservatively treated patients with a is single cerebral aneurysm. Trans Neurol Assog 1973;98:148-50.

${ }^{4}$ Nibbelink DW, Torner JC, Henderson WG. Intracrania蛋 aneurysms and subarachnoid haemorrhage. A $\cos \rightarrow$ operative study: antifibrinolytic therapy in recent $T$ onset subarachnoid haemorrhage. Strokes 1975; 6:622-9.

5 Perret G, Nishioka $\mathrm{H}$. Report of the co-operative stuet of intracranial aneurysms and subarachnoid haem rhage. Section 4. Cerebral angiography. An analysis $\overrightarrow{0}$ the diagnostic value and complications of carotid and $v$ cerebral angiography in 5484 patients. $J$ Neurosurg 1966;25:98-113.

- Dublin AB, French BN. Cerebral aneurysmal rupture during angiography with confirmation by computed $\bar{O}$ tomography: A review of intra-angiographic aneurysmal rupture. Surg Neurol 1980;13:19-26.

${ }^{7}$ King BD, Harris LC, Greifenstein FE, Elder JD, Dripps RD. Reflex circulatory responses to direct laryngo- $\frac{0}{3}$ scopy and tracheal intubation performed during general anaesthesia. Anesthesiology 1951;12:556-66.

8 Wycoff CO. Endotracheal intubation: effects on blood pressure and pulse rate. Anesthesiology 1960; 21: 153-8.

${ }^{9}$ Forbes AM, Dally FG. Acute hypertension during induction of anaesthesia and endotracheal intubation in normotensive man. Br J Anaesth 1970;42:618-24.

${ }^{10}$ Prys-Roberts C, Greene LT, Melocke R, Foex P. Studies of anaesthesia in relation to hypertension. II Haemodynamic consequences of induction and endo- 음 tracheal intubation. Br J Anaesth 1971;43:531-47.

" Prys-Roberts C, Melocke R, Foex P. Studies of anaesthesia in relation to hypertension. I Cardiovascular $\mathrm{N}$ responses of treated and untreated patients. $\mathrm{Br} J \mathrm{O}$ Anaesth 1971;43:122-37. 
12 Takeshima K, Noda K, Higoki M. Cardiovascular response to rapid anaesthesia induction and endotracheal intubation. Anesth Analg 1964;43:201-8.

${ }^{13}$ Weintraub HD, Heisterkamp DV, Cooperman LN. Changes in plasma potassium concentration after depolarizing blockers in anaesthetized man. $B r J$ Anaesth 1969;41:1048-50.

${ }^{14}$ Masson AHB. Pulmonary oedema during or after surgery. Anesthesia Analg 1981;43:440-51.

15 Russell WJ, Morris RG, Frewin DB, Drew SE. Changes in plasma catecholamine concentrations during endotracheal intubation. Br J Anaesth 1981;53:837-9.

${ }^{16}$ Editorial: Catecholamines and the heart. Lancet 1969;i: 1200.

${ }^{17}$ Savage TM, Dubois M, Frank M, Holly JMP. Preliminary investigation into a new method of assessing the quality of anaesthesia: the cardiovascular response to a measured noxious stimulus. Br J Anaesth 1969; 41:409-12.

${ }^{18}$ Denlinger JK, Ellison N, Ominsky AJ. Effects of intra- tracheal lignocaine on circulatory responses to tracheal intubation. Anesthesiology 1974;41:409-12.

${ }^{19}$ De Vault M, Greifenstein FE, Harris LC. Circulatory responses to endotracheal intubaton in light general anaesthesia - the effect of atropine and phentolamine. Anesthesiology 1960;21:360-2.

${ }^{20}$ Curran J, Crowley M, O'Sullivan G. Droperidol and endotracheal intubation. Attenuation of pressor response to laryngoscopy and intubaton. Anaesthesiology 1980;35:290-4.

${ }^{21}$ Prys-Roberts C, Foex P, Biro GP, Roberts JG. Studies of anaesthesia in relation to hypertension. $\mathrm{V}$. Adrenergic beta-receptor blockade. $\mathrm{Br} J$ Anaesth 1973;45:671-81.

${ }^{22}$ Girvin JP. The use of antifibrinolytic agents in the preoperative treatment of ruptured intracranial aneurysms. Trans Am Neurol Assoc 1973;98:150-2.

${ }^{23}$ Volby B, Eneroldsen EM. Intracranial pressure changes following aneurysm rupture. Part 3: Recurrent haemorrhage. J Neurosurg 1982;56:784-9. 